\title{
Música Popular Black and anti-racist struggles: musical cosmopolitanism and the soul aesthetic in Brazil (1963-1978)1
}

\section{David Treece}

\begin{abstract}
This essay reassesses the political significance of the creative impulses, performance aesthetics and artistic work that became identified collectively as Música Popular Black, and their contribution to the anti-racist cause in Brazil during the 1964-85 dictatorship. It re-evaluates how the state orthodoxy of racial nationalism and denialism was challenged, not merely in the adoption of the soul aesthetic as a marker of diasporic identification with US Blackness, but in the cumulative emergence of an autonomous anti-racist consciousness and voice for Afro-Brazilians within their own musical and social world. This was expressed, not only in a body of powerfully explicit antiracist statements but also in a creolized, cosmopolitan idiom of vocal and performative style that connected local artists and the Black Rio dance scene, and that contributed to the building of a Black public sphere, leaving a potent legacy for the musical and political movements of the 1980s, 1990s and beyond.
\end{abstract}

\footnotetext{
${ }^{1}$ The research for this essay was funded by Leverhulme Foundation Major Research Fellowship MRF-2018-020.
} 
Treece, David. Música Popular Black and anti-racist struggles: musical cosmopolitanism and the soul aesthetic in Brazil (19631978).

Any analysis of the relations between popular music-making and the politics of anti-racism in contemporary Brazil will inevitably focus on the period from the mid-1960s to the late 70s, which was a crucible of cultural-political creativity and activism that has left a rich and potent legacy. Besides some of the most original work from individual Black artists such as Jorge Ben, Gilberto Gil, Tim Maia and Milton Nascimento, these years gave rise to the blocos afro of Bahia's Black renaissance, including Ilê Aiyê and Olodum, to the Quilombo project and the interventions of radical roots sambistas such as Candeia, Nei Lopes, Clara Nunes and Martinho da Vila, and to the mass phenomenon of Black Rio, Brazil's Movimento Soul. Nearly all of these artists and initiatives contributed to and supported the emergence of the period's most significant anti-racist organization, the Movimento Negro Unificado (MNU), founded in 1978, and as such many went on to suffer victimization at the hands of the Brazilian State, along with other activists (Madeiro, 2019).

For this period was also dominated by the most repressive years of the 1964-85 military dictatorship, which undertook to stifle anti-racist initiatives and discourses as a key priority of its ultra-conservative nationalist agenda. In its pursuit of intensive and rapid economic growth at all costs, the military State was firmly committed to enforcing the regime of class racism it had inherited, and it would correctly interpret any emancipatory claims on the basis of 'ethnicity' as potentially overflowing into challenges of a democratic and anti-capitalist nature. As Karin Sant'Anna Kössling observes, the prospect of a Black movement protesting racism and so exposing the real contradictions and fissures dividing the country would pose an intolerable challenge to the dictatorship's official rhetoric of 'social peace' and 'national integration' (Kössling, 2007, pp. 20-21). Deeming racism to be 'non-existent' in Brazil, the State institutionalised a tradition of denialism dating back to the 1940s, with the National Security Council in 1969 declaring it an act of 'leftist subversion' to write or speak about the issue of racial discrimination (Alberto, 2011, p. 249). The regime's anxieties about any such challenges to the racial order were heightened by the fact that the same period was marked by a number of historic struggles for Black liberation internationally: the US Civil Rights and Black Power movements; a new phase in the struggle against the South African apartheid system; Rastafarianism and Pan-Africanism in the Caribbean; and the anti-colonial national liberation struggles in Portugal's African territories. All these movements fuelled and informed the interest that young Afro-Brazilians were taking in their own destinies.

Given this context, far from occupying separate domains, cultural and political expressions of activism necessarily flowed into each other. This was not lost on the regime's security forces, especially when hundreds of thousands of young working-class Afro-Brazilians began to flock to the Bailes Black of Rio de Janeiro's northern suburbs to dance to recordings of US soul and funk artists. Regardless of the real extent of any material evidence for an incipient insurrectionary movement emerging from the Rio de Janeiro dance parties, the regime was sufficiently alarmed by the mobilizing potential of the soul phenomenon among large numbers of young Afro-Brazilians for 
Treece, David. Música Popular Black and anti-racist struggles: musical cosmopolitanism and the soul aesthetic in Brazil (19631978).

it to include the surveillance and persecution of musicians and music producers among its repressive activities (Fiúza, 2006, pp. 120, 214).

How, then, should we evaluate the political meaning of the creative impulses, performance aesthetics and artistic work that became identified collectively as Música Popular Black, and their contribution to the anti-racist cause in Brazil during those years? In addressing this question, we cannot avoid the reality that, in contrast to the scenario in the United States, the emergent AfroBrazilian cultural and political activism of the period did not produce a mass anti-racist movement that could pose any serious strategic challenge to the legitimacy of the racial regime or significantly shift the balance of forces in the direction of its own interests and demands, indeed it has yet to do so. But should we-especially in the light of the severely repressive conditions it faced-judge the political significance of Música Black purely in these terms, only according to the degree to which it did or did not translate directly into organised mass militancy and insurrectionary action? Was its potential limited exclusively to the ideological challenge it posed to the official racial doctrine of mestiço nationalism, as young Afro-Brazilians looked outwards, beyond their own cultural traditions, to an external, diasporic model of Blackness, or did Brazil's Música Popular Black also have its own, original voice? Can we go beyond the consumerist paradigms that have been deployed to explain Brazilians' identification with Afro-American music as simply the 'adoption' of ready-made US versions of musical and 'ethnic' identity, as if there were no local creative agency at work in the development of a homegrown soul aesthetic and politics in Brazil?

My examination of the above questions is prompted by appreciative but critical readings of three key studies of Black Rio and the Movimento Soul published in English from the early 2000s onward. Significantly, perhaps, all of them are written from a North American perspective: 'Black Pau: Uncovering the History of Brazilian Soul' (Bryan McCann, 2002); 'Black Rio' (Christopher Dunn, 2016); and 'When Rio Was Black: Soul Music, National Culture, and the Politics of Racial Comparison in 1970s Brazil' (Paulina L. Alberto, 2009).

Bryan McCann's pioneering essay acknowledges that, in embracing a US model of Black identity, the movement implicitly contested the integrationist, consensual assumptions of Brazilian 'racial democracy'. But it is rather dismissive about what the implications were for the politics of music-making itself; these, according to McCann, were limited to asking how musicians might conceivably 'make Brazilian popular music any blacker than it already was', either by seeking inspiration in self-consciously Black cosmopolitan music or African musical expressions or by explicitly labelling their efforts as 'Black' (McCann, 2002, p. 45). Beyond this, he is overly sceptical about the importance of the political memory and legacy of Brazilian soul for subsequent generations and about its ability to resist being absorbed into mainstream nationalist discourses and 
Treece, David. Música Popular Black and anti-racist struggles: musical cosmopolitanism and the soul aesthetic in Brazil (19631978).

markets. For its immediate followers, meanwhile, McCann argues that the question was chiefly one of socio-economic mobility:

To the degree that soul had political implications for them, those implications derived from the transgression of social boundaries that soul style entailed. After all, soul was - for the majority of its participants - a celebration of new popular cultural options afforded by growing market power (McCann, 2002, p. 50).

Christopher Dunn (2016) agrees. While the soul dances may have served to a limited extent as recruiting grounds for the MNU, with several producers signing up to its founding manifesto, for Dunn 'the soul movement was more about transgressing social conventions than about political organising. It was a movement heavily focused on the management of appearance and the display of embodied competencies, especially through dance' (Dunn, 2016, p. 173). Indeed, Dunn argues, it was rather as a 'counter-cultural' alternative to political mobilisation that soul music became a focal point among Afro-Brazilian youth in their search to forge new collective identities (Dunn, 2016, p. 151). As for the artists of the period, although Dunn outlines some of the more overt thematic references to blackness in the work of Wilson Simonal, Jorge Ben, Dom Salvador, Erlon Chaves and Toni Tornado, in his account there is little sense of how musical style, voice and performance might have been expressive of an anti-racist politics. He concludes instead that 'soul music was largely disconnected from notions of Black identity, pride, and empowerment when it first began to circulate in Brazil. It was just another international pop style that could be consumed as a passing fad' (Dunn, 2016, p. 159).

Paulina L. Alberto's essay (2009) is the most thoroughly researched account of the soul dance phenomenon of the mid-1970s, and especially of the remarkably hostile reception that soul suffered from conservative intellectuals, sections of the cultural left, the media, and the police state. This reaction was precipitated by the publication of journalist Lena Frias's sensational 1976 report, pointedly titled 'Black Rio: the (imported) pride of being Black in Brazil' (Frias, 1976). As Alberto rightly argues, the traditionalist guardians of national-popular cultural authenticity converged with the racial denialists in their exaggerated, even hysterical attacks on the 'separatism' they attributed to the soul dances, accusing them variously of reverse racism, cultural 'alienation' and 'commercialism'.

Importantly, Alberto situates this analysis within a broader argument about the viability of comparison and dialogue between the Brazilian and US racial systems. She advocates the possibility that scholarly approaches to 'race relations' in Brazil and the United States (and presumably activist politics as well) might be able to transcend the dichotomy between, on the one hand, indiscriminate 
Treece, David. Música Popular Black and anti-racist struggles: musical cosmopolitanism and the soul aesthetic in Brazil (19631978).

comparison with the North American experience and, on the other, uncritical adherence to the notion of Brazil's racial exceptionalism. Alberto advocates a more nuanced attempt to understand Brazil on its own terms which will allow scholars 'to explore the ways that racial politics, identities, and discrimination can exist just as vividly in Brazil as they do in the United States, though with distinct dynamics and manifestations. At the same time, the presumption of a wholly bounded Brazilian racial system, with no overlap or exchange with the United States, no longer holds up' (Alberto, 2009, p. 7). Alberto's key insight here lies in drawing attention to the popularization of the untranslated English term 'Black' within Brazil's musical and activist circles 'without it necessarily being substituted for the Brazilian word negro' (Alberto, 2009, p. 8). In this way, we could say, Black might have become expressive of original cultural and political meanings lying somewhere between Brazil and the US, between the local and the cosmopolitan-therefore rendering obsolete the language of cultural 'borrowing' or 'importation'. However, while intriguing, this insight is not followed through by Alberto in terms of the relationship between politics and aesthetics, or its musical interpretation within the creative practices of Brazilian soul artists.

In what follows, I explore some key features of the cultural logic of Música Popular Black that, as I have suggested, the above three accounts leave unexamined or inadequately addressed, thereby underestimating its originality and its potential as a resource for building a tradition of anti-racist politics in Brazil. In undertaking this reappraisal I am indebted to the insights offered by some of the more recent Brazilian scholarship (Alonso Ferreira, 2007; Gonçalves, 2011; Lima, 2017; Morais, 2016; Oliveira, 2015; Palomo Alves, 2010) and to the wealth of new documentary and interview material made available in Zé Octávio Sebadelhe and Luiz Felipe de Lima Peixoto's 1976 Movimento Black Rio (2016).

First, I propose that we re-evaluate how the orthodoxy of racial nationalism and denialism was challenged across the 1963-78 period, not merely in the adoption of the soul aesthetic as a marker of diasporic identification with US Blackness, but in the cumulative emergence of an autonomous anti-racist consciousness and voice for Afro-Brazilians within their own musical and social world. In part, this was expressed in a body of powerfully explicit anti-racist statements in the song-texts and performances of the period. But beyond this discursive, thematic anti-racism, it was located in the development of an idiom of vocal and performative style that connected local artists of the period and the Black Rio dance scene and contributed to the building of a Black public sphere with its own distinctive and authentic voice. Here we need to ask how Afro-Brazilians were able to make soul 'their own', rendering it a meaningful expression of their experiences and aspirations, despite not sharing in the specific history of cultural and social struggles, the matrix of religiosity, gospel tradition, and Rhythm and Blues, out of which the soul impulse was forged by Black Americans. What local resources, traditions and antecedents did Afro-Brazilian artists draw upon in shaping the 
Treece, David. Música Popular Black and anti-racist struggles: musical cosmopolitanism and the soul aesthetic in Brazil (19631978).

resonances and rhythms that defined soul brasileiro: their own version of the modern, secularised voice of spiritual resilience?

Second, it is worth exploring the possibility that an ultimately more radical and durable challenge to racial nationalism was posed by the ways in which Música Black, beyond just 'borrowing' or reproducing imported US forms and styles, creatively reinterpreted and hybridized them in conjunction with the local traditions mentioned above, in a form of creolization. More than simply a process of 'mixing', the concept of creolization requires an understanding of what Robert Baron defines as 'a transformative undertaking integrating the new with the old':

Creolization involves not only continuous cultural creativity that makes the new. It engages both past and present through ongoing reinterpretation of form and meaning transmitted from the past-as a remaking of the old-as well as the creation of new forms out of the conjunctions of two or more cultures (Baron, 2003, p. 112).

In order to name this process for themselves, the artists who reinvented soul brasileiro invoked the concept of the 'Gafieira Universal' - a reference to the Rio-based popular dance parties and venues, the gafieiras, that were such a crucible of musical and choreographic innovation across much of the twentieth century (Tinhorão, 2005, p. 214). By confounding the dominant discourse's insistence on dichotomizing the 'foreign' and the 'national', this creative reinterpretation of local and international, traditional, and modern styles, in a spirit of cosmopolitan universalism, might constitute the longer-term legacy of Música Black to a Brazilian politics of anti-racism. In the absence of the critical, strategic moments of mass struggle (the Civil Rights and Black Power movements) that were vocalised in US soul and funk, the complexly composed identities of Afro-Brazilian musical expression should be seen instead as contributing to a cumulative, incremental 'war of position' (Hall, 2019, p. 78), a counter-politics of heterogeneous cosmopolitanism.

\section{The soul impulse: finding the voice of resilience and survivorhood in Black Rio de Janeiro (1963-} 70)

We should start by remembering that, even before its appearance in Brazil, far from being a narrowly delimited musical genre, US soul was an already heterogeneous, creolized and capacious complex of cultural and political values. A decade before it acquired its now familiar categorical connotations, the term 'soul' was first used most often to describe a quality of jazz or R\&B performance, an artistic 'feeling'. The shift from adjective to noun, after which 'soul' took over those collective musical meanings that the 'blues' or 'Rhythm and Blues' had signified throughout most of the 1950s, was part of the self-redefinition of African Americans that came about with the social 
Treece, David. Música Popular Black and anti-racist struggles: musical cosmopolitanism and the soul aesthetic in Brazil (19631978).

transformations and changes in political thought marking the transition from the civil rights to the Black Power eras, which was also reflected in another lexical shift, from Negro to Black. Now, besides becoming a household word among Black people following the 1964-67 inner-city uprisings of Harlem, Watts, Detroit and Newark (when, hoping to avoid looting, Black business owners displayed signs reading 'soul brother'), the term 'soul' gathered under its banner an 'extraordinarily diverse range of musical styles and sub-genres - pop soul, neo-doo-wop ballads, psychedelic rockfunk-soul, and secular gospel' (Lordi, 2020, pp. 6-7, 19, 24).[1]

Attempts to capture the significance of soul have included framing it as the spirit and cultural manifestation of an individual Black person's authentic, inner being, as an expression of their truthful 'description of the world', and even as a sonic reflection of the entire historical experience of Black people. According to Brian Ward, 'soul, like all major Black cultural forms, ultimately embodied the diversity, ambiguities, and paradoxes of the Black experience in America, as well as its common features, certainties and essences' (Ward, 1998, p. 183). But rather than an inherited 'essence' shared by Black people, or a stylistic category or repertoire, the 'soul' phenomenon that caught the imagination of Brazilian performers and listeners from the mid-1960s onward should be understood as a cultural-musical aesthetic and discourse. For Emily J. Lordi it is best characterised as a 'cultural logic of striving and resilience', that is to say, a sense of cumulative survivorship, communal belonging and emotional depth deriving from the daily experience of oppression at the hands of white supremacy - a 'recuperative logic . . . whereby suffering is made to pay off. ... Having risen above the suffering, the person gains soul'-and, having already overcome, Black people are now spiritually fortified for the necessity of doing so again (Lordi, 2020, pp. 5, 8-9).

It was, of course, the Black gospel tradition that first articulated this experience of pain, commonality and survivorship in the sacred musical language of hymn-singing. The achievement of soul was to translate that spiritual language into the profane realm of Black life, to secularize its meanings so as to meet the everyday needs of the Black working class (Neal 1999: 40). For Nelson George, the soul impulse simultaneously reinterpreted the religious passion of suffering and redemption in terms of the agony and ecstasy of individual love, as epitomized by pioneers such as blues, jazz and R\&B performer Ray Charles who, by 'unashamedly linking the spiritual and the sexual, ... made pleasure (physical satisfaction) and joy (divine enlightenment) seem the same thing' (George, 1988, p. 70).

The gospel tradition's formal and textural legacies to soul included its call and response instrumental and vocal patterns, a blend of melodic and harmonic fluidity, and rhythmic drive, reinforced by extemporaneous body moves and constructed upon a foundation of reiterative bass, drum, piano, guitar and horn figures. But, above all, it was the expressive freedom and power afforded to individual and collective vocalists that soul inherited from gospel: 
Treece, David. Música Popular Black and anti-racist struggles: musical cosmopolitanism and the soul aesthetic in Brazil (19631978).

In soul, as with all black musical forms, individual performers searched for, and the best of them found, a unique voice through which they made public private emotions and experiences with which their black audiences closely identified. For the performer, a profound sense of selfhood emerged from the full, forceful and, when appropriate, ecstatic expression of these personal truths or emotions (Ward, 1998, p. 184).

Mark Anthony Neal argues that the distinctive expressivity of gospel and soul vocalization relied upon 'tonal semantics', a special appreciation of the sonic value of the sung word, which was a legacy of the tonal languages of West Africa. This distinctive vocal musicality, or 'polytonality', with its sensitivity to variety and complexity, Neal suggests, drew upon or even mimicked the multilayered polyrhythmic structures of African instrumental ensemble playing (Neal, 1999, p. 38-40).

The soul aesthetic as outlined above did not land in Brazil on a cultural-musical blank slate. If much of what has just been described would not sound out of place in the context of mid twentiethcentury Afro-Brazilian music-making, then that is surely because parallel, if not identical developments were underway here, too, albeit on a smaller scale. Not only had a dialogue with US Black popular music already been ongoing since the early 1960s, but Afro-Brazilian musicians were also independently exploring the musical and cultural meanings we associate with the R\&B, jazz, and gospel legacies - the cultural logic of collective survival and resilience, the creative interplay between reiterative patterns and the improvisational possibilities of call-and-response, the 'soulful' spirituality and, at once, agonised and ecstatic intensity of the polytonal voice, and its embodiment in gestural moves. They did so in ways that would help to provide, at the very least, a receptive environment if not the seedbed for a local soul aesthetic in Brazil.

This was taking place at a time when Brazil's popular music industry had been overtaken by a self-consciously 'cool', modern sound, the restrained, minimalist aesthetic of bossa nova. Bossa nova's attenuated vocal and instrumental techniques and introspective, ironically urbane sophistication seemed very remote from the Black religiosity and working-class roots of samba (Treece, 2013, pp. 56-62). Indeed, as Sovik and Silva Amaral have observed, although Black musicians did contribute to the invention and production of the bossa nova style, they were generally marginalised from its public performance, and when marketed abroad bossa nova was effectively branded as 'white cosmopolitanism' (Sovik, 2009, p. 96; Silva Amaral, 2020, pp. 180-81). There was therefore a gap in the recording market, as the recording executive André Midani put it, waiting to meet the unexplored potential of a young Black audience:

So, when people ask me what the panorama of that time (in the 1960s) was like, I find that, especially in Brazil, there were the following two entities: one was the white student middle class, and the other, who knew what that was? I mean: in terms of a phonographic 
Treece, David. Música Popular Black and anti-racist struggles: musical cosmopolitanism and the soul aesthetic in Brazil (19631978).

market, no one knew why, for whom, how and what was to be done with that other share of the listening public. The only thing that was realised was that the music of Jorge Ben burst resoundingly onto the market for that other segment of society, a contemporary black Brazilian music with which this audience really identified (Peixoto and Sebadelhe, 2016, pp. 163-64).[2]

Before and alongside Jorge Ben, however, other local Black musicians were also already offering listeners glimpses of an alternative to the bossa nova vocal aesthetic, while simultaneously bringing the historical legacies of Afro-Brazilian musicality and religiosity to the contemporary urban scene. For example, as early as 1961 Nilo Amaro e Seus Cantores de Ébano (Nilo Amaro and His Ebony Singers), a nine-voice harmony group, were recording an eclectic repertoire ranging from US spirituals to Brazilian samba and folk classics, performed in doo-wop arrangements that showcased the group's vocal range and resonance.[3] It is worth recalling in this context future soul icon Tim Maia's early contact with doo-wop: following a brief teenage experiment with rock and roll alongside Erasmo Carlos and Roberto Carlos, during his stay in New York from 1959 to 1963 Maia sang in a vocal quartet known as The Ideals which, consisting of himself, two ItalianAmericans and one African-American, McCann describes as one of the few integrated doo-wop quartets of the early 1960s (McCann, 2002, p. 39).

From 1942 to 1970 public venues in central Rio de Janeiro, such as the Brazilian Press Association, hosted dramatic performances by Abigail Moura's Orquestra Afro-Brasileira of repertoires drawn from a range of traditions-the Northeastern maracatu, rooted in Congo coronation ceremonies, ring-dances involving song and drumming (batuques) and improvisational riddling (jongos), and liturgical chants from the religious practice of candomblé (derived from Yoruba sources) and its syncretic twentieth-century urban counterpart umbanda. Observers recounted experiencing the events simultaneously as educational evocations of slave history and as mystical rites of initiation:

Let the reader imagine an orchestra consisting of percussion, reeds, brass and piano which, before each concert ... carried out, step by step, ceremonies similar to those that precede the rituals of candomblé. Which used sanctified stage costumes and instruments which underwent purification rites at every performance. And which had a bandleader who, instead of making use of the conventional conducting gestures inherited from the classical tradition, used a language of gesture drawn from the dances of the orishas and warlike cries from the umbanda caboclos [divine beings in Amerindian form] (Lopes, 1995).

Moura's arrangements pioneered the hybrid fusion of African rhythmic and melodic forms with elements of North American big-band harmony, and his ensemble of around twenty musicians 
Treece, David. Música Popular Black and anti-racist struggles: musical cosmopolitanism and the soul aesthetic in Brazil (19631978).

combined reeds and brass with traditional percussion instruments such as the urucungo or berimbau (a stringed bow), the agogô and gonguê (pitched bells) and atabaques (tall, wooden hand-drums). Soloists sang in yoruba and bantu languages and indigenous nheengatu, and vocalist Maria do Carmo was particularly renowned for her mesmerising, trance-like performances, which on one occasion reportedly led to a mental breakdown on stage from which she never recovered.

That link between the ancestral traditions of Afro-Brazilian religious culture and the contemporary urban scene of Rio de Janeiro was further reinvigorated by an extraordinary 64-year old vocalist, Clementina de Jesus, who made her public debut in 1964 while still employed as a domestic worker, but who really shot to fame the following year in the musical Rosa de Ouro. While first and foremost a devout Catholic, who was actually 'discovered' singing at the Sunday festivities of Our Lady of Glória (Fernandes, 2015, pp. 150-51), there is no doubt that Clementina was also strongly connected, like Abigail Moura, to Rio de Janeiro's Afro-Brazilian cultural traditions and popular music history-she attended the musical and religious gatherings organised by the legendary Afro-Bahian matriarch Tia Ciata in the first quarter of the century (Moura, 1995) and was present at the founding of the city's first escola de samba, Deixa Falar, in 1928. By the mid-1960s she was relatively well known within the samba communities of the Portela and Mangueira escolas as a proponent of the sambas, jongos, corimás and partidos-altos that she had learned from her former slave grandparents (Fernandes, 2015, p. 146).

Fernandes is right to question the left nationalists' tendency to idealise Clementina as ancestral mother of the nation and as the missing link to a mythologised 'Africa', her voice seeming 'to rise up out of the earth, to come from the chasm of time, provoking disturbing, ancient sentiments, calling up memories perhaps of that Black Eve, the African progenitor of the whole human race' (Frias, 2001, p. 19). But that idealisation does not detract from the impact of Clementina's voice, presence and style of singing as a new aesthetic, utterly at odds with what audiences had been accustomed to until then. As the producer of Rosa de Ouro, Hermínio Bello de Carvalho, put it, she did not fit any of the vocal prototypes of the time: 'she was the antithesis of the introspection of João Gilberto and Nara Leão, models of bossa nova which had emerged six years before' (Bello de Carvalho, 2001, p. 40). Whatever her real religious affiliations, there is no doubt that Clementina's vocal sonority and performance style, as can be heard in the curimá 'Benguelê', [4] the lundu 'Bate Canela' [5] or in 'Taratá',[6] conveyed intensely the qualities of 'soulfulness', resilience and the dream of liberation that were intrinsic to those genres, whether sacred or profane.[7]

During the mid 1960s the tension between this historically grounded sonority of Black resilience and the soft-spoken 'modern' urbanity of the post-bossa, MPB voice was simultaneously being played out dramatically in collaborations between Black community-based musician activists, such as Rio sambista Zé Kéti and northerner João do Vale, and the left wing of the bossa nova 
Treece, David. Música Popular Black and anti-racist struggles: musical cosmopolitanism and the soul aesthetic in Brazil (19631978).

movement. In Oduvaldo Vianna Filho's landmark stage musical, Opinião, which had debuted within weeks of the Rosa de Ouro show in December 1964, Kéti's and Vale's resonant baritones[8] vocalised the unapologetically defiant Black working-class identity of the urban hillside favelas and the tenacity of the Northeast's rural migrants alongside, but in stark contrast to, the soft, girlish voice of Nara Leão, as their white middle-class ally (Treece, 2013, pp. 131-35).

In fact, a key thread of continuity linking the cultural archive of Afro-Brazilian religiosity, resistance and survivorship to the contemporary music scene was the passage of many artists through these radical drama and music projects on the stages of the city's nightclubs, theatres and Black recreational clubs, moving between the middle-class entertainment venues of Copacabana, on the South side, and the middle-class and lower middle-class neighbourhoods of the Zona Norte. This meant that, far from occupying an independent, segregated social and cultural ghetto, the Black musical 'underground' of northern Rio was, by the early 1970s, already connected to the city's cultural mainstream, preparing the way for the more intense exchanges that, as Luciana Xavier de Oliveira observes, would follow between the soul dance-halls and the nightclubs, record companies and print media of the Zona Sul (Oliveira, 2015, p. 80).

One of the key stage productions that undertook this migration from South to North, providing an apprenticeship for many Black vocal artists, was the musical Orfeu da Conceição (subtitled 'Black Tragedy of Rio de Janeiro'). This was poet and lyricist Vinicius de Moraes's transposition of the classical Orpheus myth to the city's hillside communities and downtown streets, which gave rise to Marcel Camus's 1959 international film adaptation Black Orpheus (sometimes known in Brazil as Orfeu do Carnaval); Tony Tornado, a key soul performer of the 1970s, was among those who auditioned for a part in the movie (Palomo Alves, 2010, p. 45). Featuring an all-Black cast drawn from Abdias do Nascimento's Black Experimental Theatre, the first stage production opened in the city's Municipal Theatre in 1956, before being taken up in other local venues.

Among the most significant of these, for our purposes, was the Renascença Clube, a recreational, cultural and sports club founded in 1951 by twenty-nine middle-class Black professionals, initially in Méier and, from 1958, in Andaraí, both of these being among the oldest neighbourhoods of the Zona Norte (Lima, 2017, pp. 48-49).[9] Following a period from the mid 1960s to the mid 1970s, when 'Rena' was opened up to a white male clientele attracted by mulatta beauty contests and samba parties, a younger, more politicised team, exemplified by Asfilófilo de Oliveira Filho, better known as Dom Filó, took over the management and set about injecting an ethos of Black consciousness into its activities. Dom Filó made his name in the mid-1970s as the producer of the celebrated multimedia 'Shaft Nights' - at which scenes from US Blaxploitation movies and the Wattstax documentary were screened - and as MC of Soul Grand Prix, one of the movement's most successful sound systems (Dunn, 2016, pp. 160-64). However, Dom Filó's first initiative in 1972 had 
Treece, David. Música Popular Black and anti-racist struggles: musical cosmopolitanism and the soul aesthetic in Brazil (19631978).

been to stage an open-air production of the Orfeu musical at the Renascença Club (Ribeiro, 2010, p. 117). This involved sambista Martinho da Vila, reeds player Paulo Moura and actor and singer Zezé Motta, who in 1969 had toured the US with Augusto Boal's Black history musical Arena Conta Zumbi (Peixoto and Sebadelhe, 2016, p. 54).

The other vector of the South-North connection was, of course, the emergent soul dances themselves. DJ Big Boy had built a (predominantly white) audience based on his extensive record collection of rock and soul and his radio career with the Tamoio and Mundial stations, which made possible the first live baile da pesada that he produced in late 1969 with dancer Ademir Lemos at the Canecão venue in the southern neighbourhood of Botafogo. This was soon transferred northwards (to the Astória Futebol Clube in Morro da Mineira near the central district of Catumbi), as other dance-parties were already springing up further North. By the early 1970s, a new territorial division of labour was emerging across the city: 'The South zone was Big Boy's and Ademir's, the Harbour District and Centre belonged to Funky Santos, the Leopoldina, Méier and Cascadura Districts to Soul Grand Prix, but from Madureira onwards-Oswaldo Cruz, Bento Ribeiro, Marechal Hermes, Rocha Miranda, it was all Black Power' (Essinger, 2005, p. 25).

We can therefore see how the cultural scene out of which Brazil's soul movement emerged was already deeply enmeshed in a dense fabric of musical currents and exchanges connecting different generations, traditions, and experiments in Afro-Brazilian self-expression across the city. To find its voice, Música Popular Black took on a further, crucial dimension through the vocal inflections and performance styles of artists such as Gerson King Combo, Jorge Ben and Wilson Simonal. From the early 1960s onward, these artists broke with the bossa aesthetic by bringing their own modern, cosmopolitan sensibility, shaped out of a dialogue between samba, jazz and R\&B, to produce a style variously referred to as samba-jazz, sambalanço, or samba-rock.

Best known for his later association with the Black Rio scene and his post-1976 dance-club hits, Gerson King Combo (Gerson Rodrigues Cortes) was raised in the samba stronghold of Madureira, and began his artistic career in 1963, dubbing Little Richard on TV Rio's Saturday afternoon show 'Hoje é Dia de Rock' (Today's Rock Day). Inspired to adopt his stage name by US saxophonist King Curtis, whose band played rhythm and blues, jazz and rock and roll, he joined the Tijuana brass group Fórmula 7,[10] and with them he made the transition towards a soul-focused repertoire which, by the end of the decade, was attracting audiences in both the Zona Norte and Zona Sul. From here he went on to perform at the 1970 bailes da pesada produced by DJs Big Boy and Ademir Lemos, becoming known as the 'dance king' and the 'Brazilian James Brown' (Oliveira, 2019, p. 7). Arguably more interesting than his 1977/78 hit albums (which are barely distinguishable from US soul), the recordings from this earlier period,[11] made together with A Turma do Soul and vocal trio 'Os Diagonais', offered original interpretations of samba and other MPB classics in soul, rock, 
Treece, David. Música Popular Black and anti-racist struggles: musical cosmopolitanism and the soul aesthetic in Brazil (19631978).

and R\&B styles, such as 'Na Baixa do Sapateiro' (Ary Barroso, 1938) and 'Aos Pés da Santa Cruz' (Marino Pinto and José Gonçalves, 1942). One of the founders of 'Os Diagonais' was Genival Cassiano, who had started out in 1964 as a guitarist with the samba-jazz group 'Bossa Trio'; Cassiano would go on to make his name as not only an influential songwriter but also 'a genius at arrangements bringing together soul and MPB' (Peixoto and Sebadelhe, 2016, p. 143).

Jorge Ben (or Jorge Ben Jor, born Jorge Duílio Lima Meneses) also began his career in the early 1960s, performing in the clubs of the Beco das Garrafas, a Copacabana backstreet that was a bossa nova stronghold. In his first LP, Samba Esquema Novo (1963), on which he was accompanied by the jazz-samba band Meirelles e os Copa Cinco, he already displayed something of an AfroAmerican vocal idiom, breaking away from the 'clean', classical minimalism of bossa nova with a 'dirtier' raspiness, more playful, colloquial diction, emotive effects, falsettos, and improvised octave leaps. These are features that, as Rezende observes, would be associated with the breezy, teasing optimism of the Pilantragem trend later epitomised by Wilson Simonal (Rezende, 2012, pp. 51-52). Ben's distinctive, melismatic singing style, shifting across several successive pitches on the same syllable, has been attributed by one interviewer to his Ethiopian heritage on his maternal side-he described himself as 'half Muslim' - although it may just as likely originate from his contact with Gregorian chant during his time in a Rio de Janeiro seminary (Viola, 2020, pp. 5-6, 31). Whatever its source, as Silva Amaral argues, Ben's voice restored something that had become suppressed or denied by bossa nova, which was the samba tradition's modal character, understood as based on its vernacular appeal, its festive, dance interpretation of the song-form, and the primacy of percussive elements (Silva Amaral, 2020, p. 25).

Indeed, those who promoted and celebrated Ben's originality attributed it to his supposed Africanist credentials, labelling him variously as an 'afro-bossa-novista', the 'macumbeiro da bossa nova' (voodoo priest of bossa nova) and as a 'crioulo' (or Black) with the power to return to bossa nova the 'African, negroid roots', the 'rhythmic exuberance' and the 'primitivism' of the nation's music (Silva Amaral, 2020, p. 182). On the cover of the Samba Esquema Novo album, producer Armando Pittigliani presented Ben's 'innate musical talent' for channelling into his compositions and his playing 'all the nostalgia of the Black man's blood, all the magic of the pure, simple poetry of the authentic Brazilian, all the exciting rhythm of four centuries of civilization based on a miscegenation of races where the Black African plays the dominant role'. In other words, as Silva Amaral argues, a starkly essentialising discourse of Africanist primitivism and authenticity (also indulged in by fellow musicians Gilberto Gil and Caetano Veloso[12]) was being deployed in order to cast Jorge Ben as the atavistic Black Other of bossa nova's 'civilising', 'modernising' influence (Silva Amaral, 2020, p. 299). For sure, his re-reading of the samba tradition, as voiced in 'Ualá Ualalá' and 'Mas que nada', appealed to notions of ancestral religiosity in its inclusion of yoruba salutations to the orishas ('O ariá raió/ Obá obá obá'), references to Afro-Brazilian coronation performances and 
Treece, David. Música Popular Black and anti-racist struggles: musical cosmopolitanism and the soul aesthetic in Brazil (19631978).

umbanda entities ('Esse samba/ Que é misto de maracatu/ É samba de preto velho') and evocations of slave history. But Ben was clearly uncomfortable with being pigeonholed as the 'voodoo priest of bossa nova', and in a 1963 interview he explicitly refuted the title, insisting that he was utterly unfamiliar with Afro-Brazilian religious cults such as macumba.[13]

The fusion of a historically grounded, resilient spirituality with the modern energy of secular urban life nevertheless lay at the heart of the soul impulse, as we have seen. Although, like Jorge Ben, Tim Maia had no special connection with the world of Afro-Brazilian religiosity, the logic of the cultural discourse surrounding the movement seemed to demand that the soulfulness of his deeply resonant vibrato must likewise be rooted there. For Ivan Conti 'Mamão', the drummer with samba-soul-jazz fusion band Azymuth, Maia was 'the synthesis of that power, the musicality of Blackness personified ... rhythm'n'blues, Black song and Afro-descendant ancestrality were all already his' (Peixoto and Sebadelhe, 2016, p. 142).

It is interesting, therefore, that in the mid-1970s Maia and Ben both explored the relationship between the liturgical resonances of soul vocalization and their respective interests, not so much in the country's more ancient religious traditions, but in contemporary theology and mysticism. Maia's short-lived but very profound involvement in Cultura Racional, a modern reinterpretation of Umbanda spiritism led by Manoel Jacintho Coelho, produced the albums Tim Maia Racional Vols.1 $\mathcal{E} 2$ (1975/76). 'Bom senso' (Good sense) featured a kind of born-again proselytizer bearing witness to his life experiences in a proto-rap before exhorting the listener to heed the 'good sense' of Rational Immunization, while 'Leia o livro Universo em Desencanto' (Read the book Universe in Disenchantment) repeated the recommendation of its title with incantatory mantra-like repetitions.[14] On his 1974 album A tábua de esmeralda (The emerald tablet), Ben similarly exploited the liturgical power of reiterated modal phrases in several tracks dedicated to his interest in the esoteric topic of alchemy, including 'Os Alquimistas estão chegando Os Alquimistas' (The Alchemists are coming the Alchemists), 'Errare Humanum Est' (To err is human), and 'Hermes Trismegisto e Sua Celeste Tábua de Esmeralda' (Hermes Trismegisto and His Heavenly Emerald Tablet).

Ben's instrumental aesthetic, meanwhile, matched his vocal style with a self-taught percussive guitar technique, using a pinched thumb and index finger to strum the strings rhythmically like a plectrum, in the manner of the blues guitarists, or an open thumb and finger to execute more complex runs (rather than plucking whole chord clusters in the bossa nova style). This resulted in a modernized samba paradigm,[15] whose rhythmic hybridism set an exciting new standard but also put the artist at odds with MPB traditionalists, who saw in it a concession to the US garage rock-inspired style known as Jovem Guarda. Ben also moved away from the harmonic complexity and chromaticism of bossa nova in favour of the simpler three-chord model of the Jovem 
Treece, David. Música Popular Black and anti-racist struggles: musical cosmopolitanism and the soul aesthetic in Brazil (19631978).

Guarda (Tatit, 1996, p. 210). As a further indication of his rejection of stylistic orthodoxy, the musicians supporting Ben on the albums from this first decade included bossa nova pianist and founder of Bossa Três, Luís Carlos Vinhas, jazz drummer Dom Um Romão, Brazilian rock band The Fevers, and the Trio Mocotó, whose percussionists had first been hired to accompany samba veterans Clementina de Jesus, Nelson Cavaquinho and Cartola, and who later went on to play with Dizzy Gillespie and Duke Ellington (Viola, 2020, pp. 27-28).

The same eclecticism is evident during the formative years of Ben's contemporary Wilson Simonal (de Castro), whose career attained comparable heights of stardom but was abruptly brought to a halt in 1971. Simonal is included by Bryan McCann among Jorge Ben's 'imitators' (McCann, 2002, p. 38); however, it is fairer to say that, while certainly achieving major hits with covers of Ben compositions such as 'País Tropical', he actually forged his own musical identity out of a parallel but distinct reworking of local and international stylistic sources. The first stage in this process, from 1964 to $1965,[16]$ was a more vibrant interpretation of the bossa nova repertoire that dispensed with its muted, minimalist instrumentation in favour of the full-bodied big-band sonority of brass and reeds and the swing of hard bop jazz, reaching out beyond the genre's more intimate confines towards the bigger audiences of the popular dance-floors, the gafieiras. This tendency was also being explored by other artists from the 'Beco das Garrafas' fraternity, such as Leny Andrade and Pery Ribeiro (Morais, 2016, p. 32). From his second album of 1965, S'Imbora, Simonal went further in testing the boundaries of genre and style, adding songwriters from the MPB canon such as Geraldo Vandré, Chico Buarque and Caetano Veloso, and pioneering a new musical acronym, 'MPM' (Música Popular Moderna). The originality and challenge of MPM resided precisely in its elusively 'modern' rhythmic appeal - neither bossa nor rock, but a mix of samba, MPB and R\&B - that divided critical opinion regarding the 'artistry' or 'commercial', mass appeal of the new sound (Castro, 2008, p. 20).

The culmination of Simonal's creative trajectory in 1966-the Pilantragem aesthetic-was, according to Morais, not a rupture with, but a continuation of, this development (Morais, 2016, p. 164).[17] Combining the electric guitar and bass of Jovem Guarda group The Fevers, and César Camargo Mariano's hard bop jazz-samba trio Som Três, its musical language joined the brash modernity of pop-rock with the swing and glamour of 'boogaloo, the Latin jazz made for the dancefloors, the lounge jazz of the Tijuana Brass, the Latin vibe of Chris Montez, Sérgio Mendes \& Brasil '66' (Alonso Ferreira, 2007, p. 26). Simonal's performative rhetoric, meanwhile, brought together a teasing, boastful, macho exhibitionism, smart, knowing irony, mockery and a glitzy display of conspicuous consumption, all of which suggested an updated, post-TV version of the playful malandro aesthetic that had informed the samba imaginary of the 1930s and 40s.

But whereas the malandro's streetwise art of evasion, drawing on verbal and choreographic agility, offered the working-class, post-Abolition Afro-Brazilian a precarious route to survival in the 
Treece, David. Música Popular Black and anti-racist struggles: musical cosmopolitanism and the soul aesthetic in Brazil (19631978).

marginal world of petty crime, hustling and samba parties (Treece, 2013, pp. 34-42), Simonal's pilantra aspired to a more glamorous status of hipster cool that was modern and cosmopolitan in its playful creativity and self-assuredness. For Alonso Ferreira, this demanded not only an impression of casual, relaxed spontaneity in its approach to the art of song, but also great technical refinement and an appreciation of stylistic fusion, the melding of tradition and innovation: 'the emphasis was on ... the free character, multiple possibilities and different influences. It was about modernizing the music while neither ignoring the past nor rejecting the foreign sound' (Alonso Ferreira, 2007, p. 26). The expressive symbol of this version of Black musical cosmopolitanism was Swing (Simonal won the title 'o rei do suingue', the king of swing), the modern counterpart to the ginga of samba and capoeira. Suingue was a faculty of bodily movement, vocalization and attitude that not only rivalled the appeal of pop-rock in its charisma and capacity to move audiences to get up and dance, but which also enacted a new idiom of racial self-confidence that arguably prefigured soul itself.

\section{Soul brasileiro and hybridity: challenging musical nationalism and sectarianism with the Gafieira Universal}

If the emergent Música Black aesthetic was therefore an eminently modernising project, a 'free fusion of foreign sonorities (from jazz and soul to Latin rhythms) and Brazilian ones (from bossa nova to samba revisited)' (Hermeto, 2012, p. 124), then where did that leave the debate about musical nationalism, tradition and the soul 'invasion'? By the time that the Bailes Black came to the attention of the media and the general public in the mid-1970s, opinion seemed to be polarised between the defenders of national-popular cultural authenticity, as represented by the samba tradition, and the advocates of the movimento soul's international, diasporic version of Black cultural politics, not least among the new university-based organisations such as the Institute for Research into Black Cultures (IPCN). For the latter, the collusion of the carnival organisations and of samba itself in the conservative narratives of the state and of the culture industry had rendered them incapable of representing the interests of young Afro-Brazilians or the anti-racist cause. Meanwhile, members of the escolas de samba and the dance-goers of the soul parties were competing with each other for access to the rehearsal and performance spaces of Rio's northern suburbs (Treece, 2018, pp. 168-70).

One apparent protagonist of the anti-soul cause was roots sambista Candeia (Antonio Candeia Filho), the leader of a radically democratic, anti-racist and communitarian samba project called Quilombo. In 1977 Candeia challenged the soul movement's diasporic claims in a performance of his composition 'Sou mais o samba' when he publicly criticised the allegedly middle-class origins of its organisers (Alberto, 2009, pp. 26-28; Treece, 2020, p. 127). Membership of the Clube Renascença was supposedly deeply divided between the partisans of samba and soul, with few attending each other's activities on different nights (Dunn, 2016, p. 172). But in reality, according to Peixoto and Sebadelhe, there was a close alliance between the two constituencies; Dom Filó and Candeia were 
Treece, David. Música Popular Black and anti-racist struggles: musical cosmopolitanism and the soul aesthetic in Brazil (19631978).

not only both members of Renascença, but also friends and collaborators on joint projects (Peixoto and Sebadelhe, 2016, p. 116). Dom Filó has repeatedly argued that the rivalry between samba and soul was incited by the media and the music industry in order to generate publicity and sales and that, while both sides may have publicly collaborated in the polemic, they remained allies fraternally united around a steadfast communitarian identity: 'The idea was: "Let's sell some records but carry on with our partying and mixing it up"' (Peixoto and Sebadelhe, 2016, pp. 118-19; Lima, 2017, p. 97).[18] Indeed, as early as 1971, on the recording 'Saudação a Tôco Prêto', Candeia had experimented with a fusion of sacred macumba chants and funk-soul riffs, including organ and synthesizer sounds provided by Azymuth's José Roberto Bertrami.[19]

Throughout the period in question, in fact, it was the creative collaborations and hybridizations undertaken by the artists themselves, drawing on the affinities between local and international styles, that arguably did most to counter any tendencies towards sectarianism within the Black musical community. And it was these collaborations and hybridizations that most powerfully confounded the claims of the nationalist commentators and the state that the turn towards soul was an 'alienated' betrayal of the country's authentic popular tradition, thereby exposing the contradiction at the heart of mestiço nationalism, with its supposed endorsement of cultural mixing. Besides the vocalists considered above, this process of creolization was the work of an entire generation of instrumentalists and arrangers, steeped in both the communitarian musicmaking practices of the samba schools and popular orchestras, and in jazz, R\&B, soul, and funk, via earlier experiences supporting artists such as Tim Maia, Tony Tornado and Jorge Ben, and sometimes through periods of residence and study in the US.[20]

Such was the background of classically trained pianist Dom Salvador who, in 1970, recruited instrumentalists from the dance-music band Cry Babies (founded in 1959) and jazz-funk outfit Impacto 8 to form Abolição. They entered the V International Song Festival, coming fifth in the national section (which was won by Tony Tornado) with 'Abolição 1860-1960', the title explicitly referencing a history of Black struggle, like that of the band's name and their 1971 album, Som, Sangue e Raça (Sound, Blood and Race), not to mention their visual style (McCann, 2002, p. 44). Abolição gave rise to the Senzala group (named after the 'slave quarters' of the colonial plantation), whose members - saxophonist Oberdan Magalhães, trumpeter Luiz Carlos 'Barrosinho', drummer Luiz Carlos 'Batera', pianist Cristóvão Bastos and double-bassist Jamil Joanes - with the addition of Claudio Stevenson on electric guitar and Lúcio J. da Silva on trombone, formed the embryonic lineup of the Banda Black Rio, created in 1976.

As Gonçalves reminds us, with their growing focus on the Black consumer market, a number of recording labels were interested in promoting artists whose repertoire met the demand for a samba/soul/funk sound: 'soul à brasileira', as it was known. So, in 1977 CBS launched Alma 
Brasileira, consisting of nine percussionists from the Mocidade Independente de Padre Miguel samba school, while in the same year Continental released an album by singer-songwriter Mita, who performed soul compositions using samba instrumentation, replacing the string bass with a surdo bass drum and the electric guitar with a cavaquinho (Gonçalves, 2011, p. 53). But Banda Black Rio's experimentalism was much more radical and far-reaching. André Midani, the boss of WEA at the time that they released the band's debut LP, Maria Fumaça (1977), claimed with some justification that, considering its innovative conception and impact on the fate of Brazilian funk, the album remains a benchmark for Brazilian musicians: 'Black people could express themselves in many ways - without being solely restricted to samba and, at the same time, without rejecting it.'[21] The repertoire for Maria Fumaça was coordinated by Filó, who had worked with several of the musicians when compiling his second Soul Grand Prix album (Lima, 2017, p. 64). Of the ten instrumental tracks, six were composed by band members and four were covers of Brazilian popular music classics: 'Na Baixa do Sapateiro' (Ary Barroso, 1938), 'Baião' (Luiz Gonzaga and Humberto Teixeira, 1946), 'Casa Forte' (Edu Lobo, 1968) and 'Urubu Malandro' (João de Barro and Lourival de Carvalho, 1923). Gonçalves observes a 'clear and constant transition between genres' throughout the course of the compositions, 'suggestive of a 'pendular movement' leaning one moment toward samba, the next toward soul, the next toward the gafieiras, the next toward jazz, and so on (Gonçalves, 2011, p. 97). As such, Gonçalves argues that the stylistic hybridisation at work should be seen, not as a homogenising 'synthesis', but rather as a dialogue whose constituent elements retain their distinct identities (Gonçalves 2011, p. 110).

A brief theoretical formulation of this spirit of free musical dialogue was offered in the album notes for the band's next LP, Gafieira Universal (1978):

The Gafieira [a popular dance-hall] was the place where the people would go to hear good music, with good bands and dances until the end of the night. Musically it was hugely profitable, for whether Brazilian or foreign, the songs were arranged more freely and played more to people's liking. There was a wonderful alchemy, because jazz themes were played with a samba rhythm.

There were famous gafieiras like CEDOFEITA, ELITE and ESTUDANTINA . . ., which disappeared in the early 1970s. But we are proposing to revive that alchemy.

In this work there are elements of SAMBA, JAZZ, FUNKY [sic], CHORO and SOULMUSIC, in short, the entire universality of music, which is universal in and of itself.[22]

To this project bandleader Oberdan Magalhães, in particular, brought a wealth of musical experience gained from drumming rehearsals in the Império Serrano, Portela and Mangueira samba schools, from the roots samba of the suburbs, and the jongo of the Morro da Serrinha. In his 
understanding of the 'Universal Gafieira', the dance-halls' repertoires, grounded in the basic structures of samba, first brought together foreign genres such as the polka, schottisch and bolero and then, from the second quarter of the twentieth century, the sonorities of the US jazz bands:

Culturally, the gafieira functioned like a veritable laboratory, in which the musicians would generally play after their day-to-day commitments. It almost functioned as an escape-valve for them, for they would experiment new kinds of arrangements and solos. As for the orchestration, the gafieira served to enable the musicians to create the most varied improvisations. Boleros were played in a samba rhythm, carnival tunes were adapted with different arrangements, etc.[23]

Magalhães's successor as leader of a second-generation Banda Black Rio, his son William, has suggested that, in the case of soul brasileiro, one key to this facility for creative dialogue across local and international styles, the gafieira principle, perhaps lies in a rhythmic affinity or kinship between its constituent parts:

there's a great natural and mathematical affinity between the styles of funk and samba, which can be explained in terms of the division of the beats. While the funk beat is played in a $4 / 4$ time-signature, the samba beat is in $2 / 2$, which creates a perfect dovetailing of the rhythms as they're fused together (Peixoto and Sebadelhe, 2016, p. 123).

Citing vocalist Gerson King Combo, authors Peixoto and Sebadelhe speculate that this explains, in part, the longevity of soul within the musical culture of Rio de Janeiro's suburbs: 'anyone who's good at samba, dances soul and funk well, too. In Brazil, we dance funk in our own way. And we make funk in our own way. That's what the gringos find astounding' (Peixoto and Sebadelhe, 2016, p. 124).

\section{Black stardom and the performance of anti-racism}

This spirit of creolisation (already a longstanding feature of Brazilian culture) was therefore central to the development of the Música Black aesthetic from the start. Throughout the period, a dialogue between contemporary cosmopolitan sonorities and local music genres, especially samba and bossa nova, continued to characterise the work of artists such as Jorge Ben and Wilson Simonal, despite the latter's conservative, nationalist tendencies, as they entered the realm of mass popularity (Morais, 2016, p. 177). 
Treece, David. Música Popular Black and anti-racist struggles: musical cosmopolitanism and the soul aesthetic in Brazil (19631978).

Simonal's early successes had already led in 1965 to an invitation to present TV Tupi's music show Spotlight. His performance of the Pilantragem aesthetic, which continued across the four studio albums titled Alegria, Alegria, now brought him a contract with TV Record, the biggest channel at the time. From 1966 he fronted the Show em Si...Monal, presenting Jovem Guarda idols and newer faces from the MPB stable. Simonal was therefore the first Black singer in the country's history to present a TV programme, and after a hugely successful show in the Maracanãzinho arena, where he upstaged Sergio Mendes's main act, the Shell company signed him for advertising promotions on TV and in newspapers and magazines. He became one of Brazil's highest selling recording artists and in November 1969 a survey ranked him the third most popular singer in the country after Roberto Carlos and Agnaldo Timóteo (Alonso Ferreira, 2007, p. 13).

Simonal's chief rival for the title of first Afro-Brazilian popular artist to become a 'mass idol'[24] was Jorge Ben. As we have seen, Ben's initial star projection as a radical innovator in the early 1960s was couched in highly racialized, primitivist language, which foisted on him the role of re-Africanising the 'whitened' aesthetic of bossa nova. But by the end of the decade, Ben seemed to have settled more comfortably into that role, and he appeared to be taking the cosmopolitan heterodoxy of the Música Popular Black aesthetic toward a vision of racial and musical liberation. At least that is what was promised by the cover image of Ben's eponymous 1969 album; this depicted the artist's naked torso and his wrists in manacles that have been broken, freeing him to hold and play his guitar. 'Take it easy my brother Charles' laid claim to a kind of universal emancipation announced by a contemporary age of human possibilities and conquests: 'Take it easy, my brother of colour/Since the first man/ Amazingly stepped onto the moon/ I've felt I had rights and principles/ And the dignity to free myself.' [25] And in 'Charles Jr', from the following year, Ben referenced the 1871 abolitionist 'Law of the Free Womb' in order to proclaim a liberation now realised, a century on: 'For I'm not (no no) what my brothers were (no no)/ For I was born from a free womb (go on, go on)/ I was born from a free womb in the $20^{\text {th }}$ century'.[26]

However, as a statement of fact, this declaration suggests that, for Ben, in Brazil Black liberation was not something that needed to be fought for, but merely celebrated in a musical language of joyful positivity and festivity. When asked in 1969 about the Black Power mobilisations in the United States, and the struggle against prejudice and racial inequality, he replied: 'It's a serious problem, right, but I'm Brazilian'.[27] Rather than the politics of Black Power, therefore, it was the 'Black is Beautiful' agenda that Ben drew from the North American experience, translating it into the title of his 1971 album Negro é lindo, and into the key themes of Afro-Brazilian identity that he explored thereafter: the aesthetic assets of the female negra, and their counterpart in masculine models of historical military heroism or contemporary sporting prowess. Although not hypersexualised as in many popular representations of the time, Ben's portrayals of Black femininity nevertheless did not venture far beyond two familiar tropes: the noble, dignified matriarch (as 
Treece, David. Música Popular Black and anti-racist struggles: musical cosmopolitanism and the soul aesthetic in Brazil (19631978).

embodied in 'Criola' and 'Sílvia Lenheira', both tributes to his Ethiopian-born mother) and the seductive, mischievous object of male erotic desire (as in 'Zula', 'Que nega é essa' (Who's that Black girl?) and 'Menina mulher da pele preta' (Black-skinned girl-woman). As such, these stereotypes did not depart significantly from traditional representations of the mulata and baiana in popular culture (Gilliam, 1998; Carvalho, 2000).

As for Ben's male icons, his sporting high-achievers (heavyweight champion Muhammad Ali in 'Cassius Marcelo Clay'-'soul brother, soul boxer, soul man' - and the African striker immortalised in the funk groove of 'Ponta de lança africano (Umbabarauma)' ) were exalted as superheroes but without any further commentary or reference to racial politics. His Saint George ('Jorge da Capadócia', Rio de Janeiro's unofficial patron saint, worshipped in syncretic form in several AfroBrazilian religions) was Ben's guardian angel protecting him from harm, while 'Charles, Anjo 45' was a latter day knight of the road, a Black Robin Hood of the favela. Of the historical role-models, it was 'Zumbi', his 1974 portrayal of the warrior king of the seventeenth-century slave stronghold, the Palmares Quilombo, that became the most inspirational for Brazil's Black activists, particularly after the release of a powerful new arrangement on the África Brasil album, using funk instrumentation and riffs, in 1976, at the height of the movimento soul: 'I want to see when Zumbi comes/ I want to see what's gonna happen/Zumbi is the lord of wars/Zumbi is lord of intents/ When Zumbi comes, it is Zumbi who will command.'[28] Even here, though, the idea of 'Black power' is invoked as immanent in Zumbi's semi-divine and royal ancestral identity, rather than as an insurrectionary agency in resistance to the colonial order. As Rezende argues, Jorge Ben's Black heroes were more typically negotiators, promoting universal peace rather than confronting white power (Rezende, 2012, pp. 130-32). Taken together with his female icons, these uncomplicated, celebratory representations of the beauty of negritude did not test or unsettle any of the assumptions of Brazilian nationalist ideology. Indeed the Negro é lindo album was well received by the press, which was happy 'to praise the union of beauty and Blackness when integrated into the national culture' (Reis, 2014, p. 14). As the title song put it: 'I just want God to help me/ See my son be born and grow up/ and be a champion/ Without hurting anyone, because/ Black is beautiful.'[29]

Meanwhile, the struggle for Black achievement and recognition, as dramatized in the career and performances of Wilson Simonal up to 1971, did not look so smooth and unproblematic; the frictions it generated arguably exposed and challenged the racial regime far more expressively than did the voice of Jorge Ben. So what was Simonal's position on the racial question during these years, as the military dictatorship entered a hard-line phase of repression, the so-called 'coup with the coup', and institutionalised its rhetoric of denialism? According to McCann, '[Simonal] did not ... give any hint of the "black soul" consciousness that would characterize the mid-1970s, and he avoided political statements of any nature. As a result, he was seen by many as a toady to the military regime, inaugurated in 1964' (McCann, 2002, p. 38).

B RASILIANA: Journal for Brazilian Studies. Vol. 10, No. 2, 2021. ISSN 2245-4373. 
Treece, David. Música Popular Black and anti-racist struggles: musical cosmopolitanism and the soul aesthetic in Brazil (19631978).

In reality, however, Simonal's undeserved reputation as a servant of the dictatorship - which all but destroyed his career-owed less to his political views and more to his uncomfortably close relationship with two officers of the regime's secret police, the DOPS, and their unproven accusations that he was a stool pigeon, following the 1971 kidnapping and assault of his former accountant Raphael Viviani.[30] In July 1968, by contrast, in response to the violent disruption of Chico Buarque's play Roda Viva at the Ruth Escobar Theatre by a far-right paramilitary group supportive of the regime, Simonal had used the platform of his TV show to take a stand and express his solidarity with the actors who had been beaten up (Morais, 2016, p. 76). Indeed, the repertoire, the stylistic choices and the views voiced publicly by Simonal during this period actually point towards a more complex politics combining conservative nationalism and unequivocal, unapologetic anti-racism. On the one hand, between 1969 and 1971 he did record a number of songs that either broadly endorsed the optimism underpinning the official patriotism of the regime-Jorge Ben's 'País Tropical' (Tropical Country) and Miguel Gustavo's 'Obrigado Pelé' (Thanks, Pelé) - or which adopted an outright, defensive chauvinism, such as Ben's 'Brasil: eu fico' (Brazil: I'm staying) and his own 'Que cada um cumpra com o seu dever' (Let each fulfil his duty), echoing government slogans like 'Brasil, ame-o ou deixe-o' (Brazil, love it or leave it) that featured in the propaganda campaign of the 1969-74 Médici administration.

On the other hand, a different dimension of his work suggests a growing sense of racial consciousness and identification. As early as 1964, the composition by Roberto Correa and Sylvio Son, 'Samba de Negro', included on the album A Nova Dimensão do Samba, set Simonal's hard bop jazz voicings in dialogue with the samba imaginary, the locus of Black working-class identity. Here he (re-) discovers the Rio hillside (like the one where he had grown up) 'to see what the Black man's got/ To dance so nice and samba like no one.'[31] By the following year, he was revisiting the favela theme through the overtly politicised filter of the protest movement, joining Zé Kéti's 'Opinião' ('they can beat me, imprison me,/ for I won't change my opinion,/ I'm not leaving the hillside') in a medley with Tom Jobim's and Vinícius de Moraes's 'O Morro não tem vez' ('the hillside never gets its time . . . but when it does the whole city's gonna sing') and Marcos \& Paulo Sérgio Valle's 'Batucada surgiu' ('The drummers came out, not a white man was left,/ For being white means you've got colour/ But not much love').[32] For Morais, the hard bop arrangement allowed Simonal to move across different geographical spaces of Black social exclusion, from the Brazilian favelas to the ghettos of the US, restoring 'Opinião' to its original significance, where it had protested the policy of favela clearance and forced relocation under Carlos Lacerda's 1960-65 governorship of Guanabara state (Morais, 2016, p. 210). In his 1970 samba-soul recording of Jorge Ben's 'Criola', Simonal contributed to the 'Black is beautiful' theme in a celebration of the 'daughter of African nobles . . . the queen of samba ... the faithful representative of Brazil'. In 'África, África' (with Ronaldo Bôscoli, 
Treece, David. Música Popular Black and anti-racist struggles: musical cosmopolitanism and the soul aesthetic in Brazil (19631978).

1971) he went as far as to reclaim his African ancestry, something that had not previously figured in his work (Morais, 2016, fn 606, p.226).

While such discursively explicit statements, however limited, are more politically significant than is often acknowledged, it was above all in his performance of cultural subjectivity - of musical idiom, sonority, and attitude (including elements of dress and choreography) - that Simonal expressed his identification with the Black cosmopolitan modernity of the soul aesthetic. Morais correctly charts a catalogue of performances from 1966 to 1969, before the arrival of soul icon Tim Maia, in which Simonal worked through the musical dialects of jazz, R\&B, soul, and funk. These range from the bluesy 'Samba do Mug' (Simonal, 1966) and 'Discussão' (Jobim/ Mendonça, 1967), through the soulful 'Sá Marina' (Adolfo/ Gaspar, 1968) - which Stevie Wonder covered in 1970 as 'Pretty World' - 'Manias' (Cavalcanti/Cavalcanti, 1968) and 'Evie' (Webb, 1969), to the gospel sound of 'Silêncio' (S. Neto/ Bittencourt, 1969) and 'Aleluia Aleluia' (Adolfo/ Gaspar, 1969), and his own funk composition ‘What you Say' (1969) (Morais, 2016, pp. 217-18).

In one outstanding instance, however, these two elements - the soul aesthetic and an overt, discursive identification with the anti-racist cause-came together in a single performance: Simonal's 1967 sambalanço 'Tribute to Martin Luther King', composed in partnership with Ronaldo Bôscoli:

\begin{abstract}
Yes, I'm a Black man of colour/ My brother, you who are my colour/ What I ask of you is, yes, to struggle, struggle more/ For the struggle is at its end . . . For every Black who's here/ Another Black will come/ To fight/ With blood or without/ With a song/ You can fight too, brother/ Hear my voice. Oh yes!/ Fight for us./ Black struggle is a struggle for peace./ So we can be equal.[33]
\end{abstract}

According to his fellow musician César Camargo Mariano, who recalls how he gave him a preview of the song during a sound-check before a show, referring to it as a 'spiritual', Simonal was intensely interested in the creation of the Black Panther Party in the United States:

it spoke a lot to him, who was becoming a star, but who not long before had been obliged to use the backdoor to enter the places where he wanted to go. This issue was always on the agenda at his shows, either as a light hearted joke, or in a serious text. And he was delighted at Martin Luther King and followed his struggle as an activist for Black rights in detail. It gave me goosebumps to hear the song he showed me, the strength of the lyric, and I saw how serious his civic consciousness was (Alexandre, 2004).

Although recorded in February 1967, the song was only released by the censors four months later, but not before Simonal had given it a surprise debut performance in March, on prime-time

B RASILIANA: Journal for Brazilian Studies. Vol. 10, No. 2, 2021. ISSN 2245-4373. 
Treece, David. Música Popular Black and anti-racist struggles: musical cosmopolitanism and the soul aesthetic in Brazil (19631978).

national television, at the annual Roquette Pinto broadcasting awards. The daily newspaper Folha de São Paulo reported on the occasion as follows: 'Here before us is a serious, focused Simonal that we haven't known before. The power of his voice addresses his Black brothers all over the world. And, symbolically, all those who have been humiliated and wronged, who are bullied and are hungry for justice.'[34] Speaking directly to the audience, Simonal dedicated the performance to his son, 'in the hope that, in the future, he will never face those problems I once faced, and have at times been facing, despite being called Wilson Simonal de Castro'.[35] Following King's assassination in April 1968 (the month of the first major industrial strike since the 1964 coup and two months before the 'March of the 100,000' against the regime), TV Record screened a special tribute show, presented by Simonal and featuring fifteen Black celebrities on stage, with huge pictures of US boxer Muhammad Ali, footballer Pelé and Simonal. Alexandre recounts some of the participants' contributions:

'In Brazil racism takes on the most detestable form, as it is social, and seemingly acceptable', stated [vocalist] Rosa Marya Colin. 'Now things are gonna have to be on the basis of violence', argued [singer-songwriter] Agostinho dos Santos. 'Here there's a subtle, evil racism, the worst kind', said [samba performer] Jamelão. Moved, Simonal preferred not to talk much, 'in order not to turn Luther King into an object', and he contributed instead by singing, reading speeches by the Reverend and presenting the programme (Alexandre, 2009, pp. 102-03).

Recalling his performances on a later occasion, Simonal remarked: 'I can challenge things, but in a gentle way. Like when I sang 'Tribute to Martin Luther King'. I can call things out, but in a friendly way, because I'm opposed to violence, to provocation.' [36] This has been interpreted as indicative of a conciliatory, non-confrontational and even accommodating attitude to power, the racial regime and anti-racist activism. For all his early interest in the Black Panthers, Simonal's public identification with Martin Luther King (as opposed to the revolutionary Malcolm X) is certainly more consistent with his stated aversion to the politics of the student and intellectual left, and with his detachment from the anti-capitalist tenor of the emergent Black movement in Brazil. Simonal's is indeed the liberal politics of racial 'uplift', of individual self-help, striving and excellence in the pursuit of social recognition, acceptance and upward mobility:

But to get change it's not through black power, black panthers and fancy stuff like that, you get change through education and the Black man showing that he's capable of asserting himself. The Black man has got to study, he's got to get by. . . any black guy who's pushy, who proves he knows how to do things properly, to lead an honest life without hurting anyone else, even your blonde pink-eyed Belgian is going to think that guy's amazing.[37] 
Treece, David. Música Popular Black and anti-racist struggles: musical cosmopolitanism and the soul aesthetic in Brazil (19631978).

But this quite conservative, individualistic approach to self-advancement did not mean that Simonal was any less conscious of the realities of prejudice; after all, he had learned these through the harsh experience of competing for recognition in a racialised order, as one who had grown up in the Praia do Pinto favela and had gone out to work barely having completed his primary education. Far from denying the scourge of discrimination, his was an economistic, rather than a political take on racism, an acute sensitivity to the hierarchy of value through which darker skinned Brazilians were relegated and demeaned, and this was entirely consistent with his struggles for success within the entertainment marketplace, where he was obliged to undo the lie of Black inferiority and prove his worth by outcompeting and outdoing his white rivals ('deixar cair', 'arrasar' or 'mandar ver' were his preferred slang terms for this):

There isn't racial segregation in Brazil, but there is social prejudice, prejudice of a financial and intellectual order. So what I don't think is good is that the overwhelming majority of Black Brazilians should be marginalised. And why is the Black Brazilian marginalised? Because he's conditioned, he's convinced himself that he's actually inferior, that he isn't capable of getting things done. Because of this social and economic problem. The Black man has to be exceptional, because there's an established convention that the White man is more intelligent than the Black, that the White man is more handsome, that the White man is cleaner. So the Black man has to prove that that's not quite the way things are.[38]

Simonal defended his preference for a glamorous, cosmopolitan stylistic chic in precisely such terms, in order to overturn stereotypical expectations of a certain kind of Black Brazilian musician ('that criminal type ... who always has to be playing the tambourine or a matchbox, and clowning around on stage' (ibid.)), which led him to claim that he would rather be booed in his Mercury Cougar than be applauded while riding on a bus (Mello, 2003, p. 196)-indeed he was quite capable of performing his 'Tribute to Martin Luther King' against the background of a luxury limousine surrounded by a host of sequinned female models. Hence the charge from those such as Vinicius de Moraes and Nara Leão, who reviled his Pilantragem aesthetic, that he was complicit in the decadent, consumerist optimism of the Dictatorship and its 'Economic Miracle' (Alonso Ferreira, 2007, pp. 12-13).

Nevertheless, Simonal's insistence on challenging such class-and-race based assumptions about Black identity also necessarily destabilised conservative, essentializing notions of nationhood, Afro-Brazilianness and the Black population's contribution to the country's history (Morais, 2016, p. 126). One remarkable example, from the Show em Si...Monal, took the form of a satirical musical sketch in which the artist, entering the stage in a clown-like costume, caricatured the role of a 
Treece, David. Música Popular Black and anti-racist struggles: musical cosmopolitanism and the soul aesthetic in Brazil (19631978).

minstrel forced to entertain the crowd beneath hails of laughter, ridicule, custard pies and other humiliations. Simonal's retort was nothing less than an act of subversion: alternating between forced smiles and serious, dramatic pauses, the musical ditty that followed, in vaudeville style, drew on his entire repertoire of ironic impudence and mockery to challenge the audience and lay bare the racist 'game' in which they were implicated:

My hair is stiff and my nose is flat. Between us, a wall, we're like cat and mouse. My skin is dark. Much darker, is my life. Black man's got no culture. Go earn a drink. I'm black, a Black man: but for the love of God, I'm a person too! Is it true or am I joking? Black people talk too much! But for the love of God, I'm a person too![39]

Interpreting the shifting, hybrid terrain of local and international styles and star-audience relations, Simonal was rehearsing some of the possibilities and constraints that surrounded an individual Black artist's emergence within, and claims over, the musical marketplace. If his preferred vehicle for this pursuit of Black stardom was the TV entertainment show, the potential that the small screen offered for mass exposure was also being explored through the televised song contests, such as the International Song Festival (FIC), which had been running annually since 1966. Broadcast by TV Globo from Rio de Janeiro's Maracanãzinho arena, the FIC became, not just a platform for the music industry to scout and promote new talent, but also a kind of surrogate political space in which rival styles, cultural agendas and ideologies competed for the allegiance of audiences and constituencies (Treece, 2013, pp. 115-18).

Soul was the latest genre to join the festival stage when, in October 1970, Tony Tornado (Antônio Viana Gomes) won the FIC national final with Antônio Adolfo and Tibério Gaspar's 'BR3'. The song had originally been offered to Wilson Simonal and Tim Maia, neither of whom could take it on, but Tornado met the songwriters' need for a soul performer with a black power, 'black hippie' vibe, so 'I took the opportunity to bring out all the facial gestures of my idol James Brown, who I'd seen so many times in shows at the Apollo theatre when I lived in Harlem' (Peixoto and Sebadelhe, 2016, p. 39). Indeed, during the eight months he spent there, Tornado also spent time in the company of several Black Panther Party members, including veteran Black Power activist Stokeley Carmichael (Palomo Alves, 2010, p. 34). As a result, Tornado says, 'I was able to absorb the Black Power craze of afro hairdos, colourful clothes, long lapel shirts and bell-bottom trousers. It was total identification, I completely adopted the style of the new blaxploitation films ... (Peixoto and Sebadelhe, 2016, p. 37). On returning to Rio de Janeiro in 1969, wearing a yellow jacket, brightly coloured shoes, and a big, dyed afro, his appearance certainly alerted the attention of the authorities, and he was taken by the police for questioning at the DOPS headquarters (Palomo Alves, 2010, pp. $67 \& 71) \cdot[40]$ 
Treece, David. Música Popular Black and anti-racist struggles: musical cosmopolitanism and the soul aesthetic in Brazil (19631978).

As for Tornado's performance of 'BR-3', given its slow waltz tempo, Dunn interprets it as remote from the $R \& B$ and gospel roots of the soul genre, suggesting that 'For fans of James Brown, and Marvin Gaye, there is little in "BR-3" that would be recognisable as soul music' (Dunn, 2016, p. 157). But this is to ignore the stirring swing that the vocalists imparted to the song, and the powerfully resonant call-and-response exchange between soloist Tornado and the backing singers of the Trio Ternura, which are surely the epitome of gospel-inspired 'soulfulness'.[41] Outwardly, 'BR-3' references a notorious highway between Rio de Janeiro and Belo Horizonte that was the tragic setting for numerous fatal accidents - 'We race along the BR-3/ And we die on the BR-3/ There's a crime on the long asphalt of that road/ And a news report's produced/ For each month's new hero'[42]. However, Mello suggests that it was intended as an oblique allusion to the dangerous political moment the country was living through (Mello, 2003, p. 380). Any such sub-text must have gone undetected by the authorities, as Tornado was congratulated for his victory in person by the President of the Republic, General Médici, no less. But he was not well regarded by the military for long. The song 'Sou Negro' ('I'm Black', Getúlio Côrtes \& Ed Wilson) left no doubt as to the political affiliations that had remained implicit, at most, in the performance of 'BR-3':

I don't know why you're so proud/ You always hold me in contempt./ I know that I'm Black/ but no one's gonna laugh at me// See if you get it, see if it helps/ My character's not in my colour/ What I want, don't be fooled/ What I'm looking for is your love.[43]

Some sources claimed that this was Tornado's real 'protest song', and when performing it on television, as he did regularly in the 1970s, he would commonly raise a fist, Black Panther style. This display of the 'communist "black power" gesture-symbol', as an Army Intelligence report put it, resulted in repeated warnings from the regime's Censorship Service for 'conveying a false image of the Brazilian reality, by aggressively insinuating a climate of racial hatred that does not exist in Brazil' (Palomo Alves, 2010, pp. 94-95). Further controversy followed when, at the next year's International Song Festival, Tornado performed Marcos \& Paulo Sergio Valle's 'Black is Beautiful' with acclaimed white female vocalist Elis Regina, who was president of the festival jury:

Early this morning, on Ouvidor Street/ I saw so many awful white guys/ I want a man of colour/ A black god from the Congo or from here/ Who'll integrate with my European blood// [In English] Black is beautiful, black is beautiful/ Black beauty so peaceful/ I wanna a black/ I wanna a beautiful[44]

The original lyric, in which a male voice called on a 'goddess of the Congo' to 'improve my European blood', was vetoed by the censors (Palombini, 2009, fn. 10, p. 46). But the revised text's transgressive declaration of interracial desire, clumsily overstated and laden with contradictions as

B RASILIANA: Journal for Brazilian Studies. Vol. 10, No. 2, 2021. ISSN 2245-4373. 
it was, nevertheless still posed a huge provocation to the denialist thinking of the regime; not least when, to Regina's plea 'I want a man of colour', Tornado answered: 'That's me. It's gotta be me!' and raised his clenched fists in the air. He was immediately led away in handcuffs and taken for questioning by the DOPS, who interrogated him on nine further occasions.[45] The official nationalist rhetoric of miscegenation did not therefore allow for any actual public displays of interracial love, real or otherwise; indeed, Tornado's off-stage relationship with white actress Arlete Sales was likewise the target of vilification in the press and in the streets (Palomo Alves, 2010, p. 103). Singer, arranger and bandleader Erlon Chaves, who was dating former Miss Brasil model Vera Fischer at the time, suffered a similar fate after performing Jorge Ben's 'Eu também quero mocotó' with his gospel-robed Banda Veneno chorus at the 1970 International Song Festival.[46] Accused of sexual harassment for a scene where he was kissed by a succession of scantily class blonde dancers, Chaves was held in a DOPS cell for several days, barred from exercising his professional activities for a month and advised to leave the country (Marsiglia, 2004). Tornado's career was also disrupted throughout the next few years, when he suffered threats and spent periods of exile in Uruguay, Angola, Egypt and Europe. But, after returning to Brazil, he resumed his interventions and clashes with the Federal authorities. For example, in 1976, his recording of Cláudio Fontana's 'Se Jesus Fosse um Homem de Cor' (If Jesus were a Man of Colour) was censored and copies on sale in music stores were smashed (Palomo Alves, 2010, p. 116-17). The song asked: 'Would you have the same love for Him/ If Jesus were a man of colour?'

\section{Concluding remarks}

Together with Tornado's stage and television appearances, Gerson King Combo's public performances were also being identified as the key link between the voice of soul brasileiro, the language of anti-racism and the spectre of mass Black mobilisation in the form of the bailes. By this time, the dance parties were being investigated by a newly reformed 'secret' or 'political' police body, the Departamento Geral de Investigações Especiais (DGIE) (Alberto, 2009, p. 8). Gerson's major 1977 hit 'Mandamentos black' (Black Commandments) may have shied away from the defiant militancy of James Brown's 'Say it loud, I'm black and I'm proud' in favour of a conciliatory call for Black brotherhood (Dunn, 2016, p. 168): 'Brother!/ Take up your mind, brother/ And reach the powerful conclusion/ That the Blacks don't want to offend anyone, brother!/ What we wanna do is dance!/ Dance, dance and dig a lotta soul'.[47] But given the authoritarian state's paranoid anxieties and the regime of censorship, this was like a red rag to a bull. Gerson was accused on radio of raising a 'Black flag' and inciting revolt (Palomo Alves, 2010, p. 50), and his live show was closed down before he could go on stage (Marsiglia, 2004). In October that year, a hysterical editorial by journalist Ibraim De Leve informed readers of the daily O Globo that a group in Brazil's music scene, led by Gerson King Combo and Tony Tornado, was trying to launch a 'black power' movement in Brazil 
Treece, David. Música Popular Black and anti-racist struggles: musical cosmopolitanism and the soul aesthetic in Brazil (19631978).

through their shows where, allegedly, 'negros take the opportunity to engage in agitation, pitting negros against whites and preaching racial domination in Brazil, after the example of the States' (Alberto, 2009, pp. 22-23).

These were absurd claims, but they do bear witness to the extent of perceived fears about the mobilising potential of Black music-making, at that transformational threshold between cultural and political meaning. At this crucial transition, 'soul lost its characteristics of pure entertainment, "grooving", an end in itself (in the discourse of the sound systems) and became a means to achieve an end - the overcoming of racism (in the discourse of the Black Movement)' (Vianna, 1988, pp. 2829). If not itself a direct instigator of political activism as such, the cumulative energies of the movimento soul did contribute to an incremental shift in anti-racist consciousness, a 'revolution of ideas' among young Afro-Brazilians, who began to question the civilizational foundations and assumptions of their society (Peixoto and Sebadelhe, 2016, p. 20). The creative work of a generation of musicians and their contribution to the building of a Black public sphere with its own distinctive voice established models of organisation, activity and self-expression that would leave a vital legacy for the funk carioca and hip-hop movements of the 1980s, 1990s and beyond (Herschmann, 2000). As such, Música Popular Black is an example of what Eyerman and Jamison claim to be the potency of cultural activism for social movements: that is to say, in remaking and mobilizing remembered traditions of resistance that can both contribute to long-term shifts in ideology and social consciousness and inspire new waves of political struggle (Eyerman and Jamison, 1998, pp. 1-10). Lordi could have equally been speaking of Brazil's Música Popular Black when she wrote that 'soul music's status as a commodity did not compromise its potential to restore one's sense of belonging to a community defined by resilience. . . soul was a "big tent" that could foster love of one's own and others' Blackness ... This love and struggle, inseparable from commerce in a capitalist society, might not translate into political action. But it gave people a . . . sense of individual and collective mattering ... that was the necessary starting point for political mobilization' (Lordi, 2020, pp. 3637).

\section{References}

Alberto, P. L. (2009) ‘When Rio Was Black: Soul Music, National Culture, and the Politics of Racial Comparison in 1970s Brazil', Hispanic American Historical Review, 89(1), pp. 3-39.

Alberto, P. L. (2011) Terms of inclusion: Black intellectuals in twentieth-century Brazil. Chapel Hill: University of North Carolina Press.

Alexandre, R. (ed.) (2004) Wilson Simonal na Odeon (1961-1971). Rio de Janeiro: EMI (booklet accompanying box-set of $9 \mathrm{CDs})$.

Alexandre, R. (2009) "Nem vem que não tem": a vida e o veneno de Wilson Simonal. São Paulo: Globo. 
Treece, David. Música Popular Black and anti-racist struggles: musical cosmopolitanism and the soul aesthetic in Brazil (19631978).

Alonso Ferreira, G. A. (2007) Quem não tem swing morre com a boca cheia de formiga: Wilson Simonal e os limites de uma memória tropical. Masters dissertation, Universidade Federal Fluminense.

Baron, R. (2003) 'Amalgams and Mosaics, Syncretisms and Reinterpretations: Reading Herskovits and Contemporary Creolists for Metaphors of Creolization', Journal of American Folklore, 116(459), pp. 88-115.

Bello de Carvalho, H. (2001) ‘Clementina: uma nova estética' in Coelho. H. (ed.) Rainha Quelé: Clementina de Jesus. Valença RJ: Editora Valença, pp.40-47.

Carvalho, J. J. de. (2000) 'The multiplicity of Black Identities in Brazilian Popular music', in Crook L. and Johnson R. (eds.) Black Brazil: Culture, Identity, and Social Mobilization. Los Angeles: UCLA Latin American Center, pp. 261-96.

Castro, R. (2008) Wilson Simonal. Coleção Folha 50 Anos de Bossa Nova. Vol. 14. São Paulo: Folha de São Paulo.

Coelho, H. (ed.) (2001) Rainha Quelé: Clementina de Jesus. Valença RJ: Editora Valença.

Dunn, C. (2016) 'Black Rio' in____ Contracultura: alternative arts and social transformation in authoritarian Brazil. Chapel Hill: The University of North Carolina Press, pp. 146-74.

Essinger, S. (2005) Batidão: uma história do funk. Rio de Janeiro \& São Paulo: Record.

Eyerman, R., \& Jamison, A. (1998) Music and Social Movements: Mobilizing Traditions in the Twentieth Century. Cambridge: Cambridge University Press.

Fernandes, D. C. (2015) 'A Rainha 'Quelé': raízes do empretecimento do samba', História: Questões E Debates, 63(2), pp. 131-160.

Fiúza, A. F. (2006) Entre um samba e um fado: a censura e a repressão aos músicos no Brasil e em Portugal nas décadas de 1960 e 1970. Doctoral thesis, State University of São Paulo, UNESP-Assis.

Frias, L. (1976) 'Black Rio: o orgulho (importado) de ser negro no Brasil.', Jornal do Brasil, caderno B, 17 July.

Frias, L. (2001) 'A saga de uma rosa negra' in Coelho. H. (ed.) Rainha Quelé: Clementina de Jesus. Valença RJ: Editora Valença, pp.13-39.

Giacomini, S. M. (2006). A Alma da Festa: família, etnicidade e projetos num clube social da Zona Norte do Rio de Janeiro - o Renascença Clube. Belo Horizonte: UFMG; Rio de Janeiro: IUPERJ/IUCAM.

Gilliam, A.(1998) 'The Brazilian “Mulatta”: images in the global economy', Race and Class 40(1), pp. 57-69.

Gonçalves, E. G. (2011) Banda Black Rio: o Soul no Brasil da década de 1970. Masters dissertation, Universidade Estadual de Campinas.

Hall, S. (2019) 'Old and New Identities, Old and New Ethnicities' in Essential Essays Vol.2. Durham: Duke University Press, pp. 63-82.

Hermeto, M. (2012) Canção popular brasileira e ensino de história: palavras, sons e tantos sentidos. Belo Horizonte: Autêntica Editora.

Herschmann, M. (2000) O Funk e o Hip-Hop invadem a cena. Rio de Janeiro: Editora UFRJ.

Kössling, K. S. (2007) As Lutas Anti-Racistas de Afro-Descendentes sob Vigilância do DEOPS/SP (1964-1983). Masters dissertation, Universidade de São Paulo. 
Treece, David. Música Popular Black and anti-racist struggles: musical cosmopolitanism and the soul aesthetic in Brazil (19631978).

Lima, C. E. de F. (2017) Sou negro e tenho orgulho! Política, identidades e música negra no Black Rio (1960-1980). Masters dissertation, Universidade Federal Fluminense.

Lopes, N. (2003) ‘O sonho de Biga: memória da Orquestra Afro-brasileira’, Direitos Já, 5, July/August 1995, reproduced in Abigail Moura - A Orquestra Afro-Brasileira. São Paulo: Museu Afro-Brasil.

Lordi, E. J. (2020) The meaning of soul: Black music and resilience since the 1960s. Durham: Duke University Press.

Madeiro, C. (2019) ‘Repressão aos negros: Documentos mostram como a ditadura espionou movimento contra o racismo, com agentes infiltrados e perseguições.', UOL Notícias, 30 March. [Online]. Available at: https://noticias.uol.com.br/reportagens-especiais/ditadura-militar-espionou-movimento-negro-reprimiue-infiltrou-agentes/\#page10 Accessed on: 26 July 2021.

Marsiglia, L. (2004) ‘O Movimento Black Rio - Desarmado e Perigoso’ Super Interessante, 206, year 18(11), 31 October.

McCann, B. (2002) ‘Black Pau: Uncovering the History of Brazilian Soul', Journal of Popular Music Studies, 14, pp. 33-62.

Mello, Z. H. de. (2003) A Era dos Festivais: uma Parábola. São Paulo: Editora 34.

Morais. B.V. L. de. (2016) 'Sim, sou um negro de cor': Wilson Simonal e a afirmação do Orgulho Negro no Brasil dos anos 1960. Masters dissertation, Universidade Federal de Minas Gerais.

Moura, R. (1995) Tia Ciata e a Pequena África no Rio de Janeiro. Rio de Janeiro: Secretaria Municipal de Cultura.

Neal, M. A. (1999) What the music said: Black popular music and Black public culture. New York and London: Routledge.

Oliveira, L. S. (2019) 'A hereditariedade, é por isso que o meu corpo treme todo: trajetória artística de Gerson King Combo', ANPUH-Brasil, 30 Simpósio Nacional de História, Recife. Available at: https://www.snh2019.anpuh.org/resources/anais/8/1564708652 ARQUIVO artigoanpuh.pdf Accessed on: 26 July 2021.

Oliveira, L. X. de. (2008) O Swing do Samba: uma compreensão do gênero do Samba-Rock a partir da obra de Jorge Ben Jor. Masters dissertation, Universidade Federal da Bahia.

Oliveira, L. X. de. (2015) ‘Visões sobre o Movimento Black Rio: apontamentos teóricos sobre estilo, consumo cultural e identidade negra', Animus, 14.

Palombini, C. (2009) 'Soul brasileiro e funk carioca', Opus, 15(1), pp. 37-61.

Palomo Alves, A. (2010) O poder negro na pátria verde e amarela: musicalidade, política e identidade em Tony Tornado (1970). Masters dissertation, Universidade Estadual de Maringá.

Reis, A. (2014) ‘O "poder negro da beleza”: a influência dos movimentos estadunidenses Black is Beautiful e Black Power na obra de Jorge Benjor', Anais do XI Encontro Internacional da ANPHLAC.

Rezende, R. S. (2012) Jorge Ben: um negro na MPB nas décadas de 1960-1970. Masters Dissertation, Universidade Federal do Estado do Rio de Janeiro.

Ribeiro, R. A. da C. (2010) ‘Errância e exílio na soul music: do movimento Black-Rio nos anos 70 ao Quarteirão do Soul em Belo Horizonte', Revista Tempo e Argumento, 2 (2), pp. 154-80.

Risério, A. (ed.) (1977) Gilberto Gil Expresso 2222. Salvador: Editora Corrupio.

B 
Treece, David. Música Popular Black and anti-racist struggles: musical cosmopolitanism and the soul aesthetic in Brazil (19631978).

Sebadelhe, Z. O. and Lima Peixoto, L. F. de. (2016) 1976 Movimento Black Rio. Rio de Janeiro: José Olympio. Silva Amaral, M. H. da. (2020) Jorge Ben, tradutor do Brasil. Doctoral dissertation, University of Brasília.

Sovik, L. (2009) Aqui ninguém é branco. Rio de Janeiro: Aeroplano.

Tatit, L. (1996) O Cancionista: Composição de Canções no Brasil. São Paulo: Edusp.

Thayer, A. (2019) Tim Maia Racional Vols 1 \& 2. New York: Bloomsbury Academic.

Tinhorão, J. R. (2005) Os sons que zêm da rua. São Paulo: Editora 34.

Treece, D. (2013) Brazilian Jive: from samba to bossa and rap. London: Reaktion.

Treece, D. (2018) 'Candeia, o projeto Quilombo e a militância antirracista nos anos 1970', Revista do Instituto de Estudos Brasileiros, 70, pp. 166-88.

Treece, D. (2020) 'Samba, Anti-Racism and Communitarian Politics in 1970s Rio de Janeiro: Candeia and the Quilombo Project' in (ed.) Music Scenes and Migrations: Space and Transnationalism in Brazil, Portugal and the Atlantic. London and New York: Anthem Brazilian Studies, pp. 125-42.

Trotta, F. (2011) O samba e suas fronteiras: "pagode romântico" $e$ "samba de raiz" nos anos 1990. Rio de Janeiro: Editora UFRJ.

Vianna, H. (1988) O mundo funk carioca. Rio de Janeiro: Jorge Zahar.

Viola, K. (2020) África Brasil: One day Jorge Ben flew for everyone to see. São Paulo: Edições Sesc São Paulo, ePUB.

\section{Notes}

[1] Lordi is referencing Brackett, D. (2016) Categorizing Sound: Genre and Twentieth-Century Popular Music. Berkeley: University of California Press, 2016, p. 294.

[2] My translation. Unless otherwise indicated, all translations from texts in Portuguese are my own.

[3] Dicionário Cravo Albin da Música Popular Brasileira. Available at: https://dicionariompb.com.br/nilo-amaroe-seus-cantores-de-ebano/dados-artisticos (Accessed: 26 July 2021)For the 1961 album Os anjos cantam see https://www.youtube.com/watch?v=aP-oKblVH c (Accessed: 26 July 2021)

[4] Available at: https://www.youtube.com/watch?v=cug-Z37wDx0 (Accessed: 26 July 2021)

[5]Available at: https://www.youtube.com/watch?v=zvIZ1IGY3ig (Accessed: 26 July 2021)

[6] Available at: https://www.youtube.com/watch?v=tAxmEQ3ml00 (Accessed: 26 July 2021)

[7] See the 1978 commentary on 'Taratá' by José Miguel Wisnik, cited in Coelho, 2001, p. 77.

[8] https://www.youtube.com/watch?v=yrbQ pDXHZs and https://www.youtube.com/watch?v=_bFl611uMfM (Accessed: 26 July 2021)

[9] See also Giacomini, 2006.

[10] See the album Fórmula 7 (1970) https://www.youtube.com/watch?v=a3fjp-bSBBg (Accessed: 26 July 2021) 
Treece, David. Música Popular Black and anti-racist struggles: musical cosmopolitanism and the soul aesthetic in Brazil (19631978).

[11] Brought together on the 1970 album Gerson Combo E A Turma Do Soul - Brazilian Soul (Polydor - 44.057), available at https://www.youtube.com/watch?v=YzjIdpPbGAQ (Accessed: 26 July 2021)

[12] See, for example, Gil's interview with Marco Aurélio Luz in Risério, A. (ed.) (1977) Gilberto Gil Expresso 2222. Salvador: Editora Corrupio, p.171, and radio documentary Imbatível ao extremo - Assim é Jorge Ben Jor! Rádio Batuta, Instituto Moreira Salles, 2012, available at: https://radiobatuta.com.br/documentario/imbativel-ao-extremo-assim-e-jorge-ben-jor/ (Accessed: 26 July 2021)

[13] Revista do Rádio 732, 28/09/1963, cited in Silva Amaral, 2010, p. 267.

[14] See Allen Thayer's detailed account of the albums in Thayer, 2019.

[15] Dubbed the 'Ben Jor pattern' by Felipe Trotta (2011, pp. 116-18).

[16] On the albums Simonal tem Algo Mais (1964), A Nova dimensão do Samba (1964) and Wilson Simonal (1965).

[17] See the albums Tempos de Pilantragem (1967) and Show em Simonal (1967).

[18] See also the 2010 TV Alerje interview with Filó: CULTNE - TV Alerj - Filó Filho Part 1, available at https://www.youtube.com/watch?v=N3C7fCE2x8s (Accessed: 26 July 2021), and his testimony in the 2020 documentary debate CULTNE - Live Baile da Pesada - 50 anos Part 1, available at https://www.youtube.com/watch?v=sXdUN xeMHM (Accessed: 26 July 2021)

[19] On the album Seguinte ... Raiz. Equipe - EQC-800004 (1971).

[20] For the following account of Banda Black Rio I am indebted to Gonçalves, 2011, pp. 51-79.

[21] Midani, A. (2008) Música, ídolos e poder: do vinil ao download. Rio de Janeiro: Nova Fronteira, p.180, apud. Gonçalves, 2011, p. 56.

[22] Album notes, Banda Black Rio. Gafieira Universal. 1978. RCAVictor.

[23] Bittencourt, S. 'Tem tudo na gafieira Black-Desde o funk até o samba', Revista Amiga Som. Cited in Gonçalves, 2011, p. 73-74.

[24] The formulation is Silva Amaral's (2020, p. 20).

[25] ‘Take it easy, meu irmão de cor/ Depois que o primeiro homem/ Maravilhosamente pisou na lua/ Eu me senti com direitos, com princípios/ E dignidade de me libertar.' See image at: https://en.wikipedia.org/wiki/Jorge Ben (album) (Accessed: 26 July 2021)

[26] 'Pois eu já não sou (não não) o que foram os meus irmãos (não não)/ Pois eu nasci de um ventre livre (vai, vai)/ Nasci de um ventre livre no século XX)'.

[27] O Pasquim 25 September 1969, pp. 9-10, cited in Reis, 2014, p. 18.

[28] ‘Eu quero ver quando Zumbi chegar/ Eu quero ver o que vai acontecer/ Zumbi é senhor das guerras/ Zumbi é senhor das demandas/ Quando Zumbi chega, é Zumbi quem manda.'

[29] 'Eu só quero que Deus me ajude/ A ver o meu filho nascer e crescer/ E ser um campeão/ Sem prejudicar ninguém, porque/ Negro é lindo.'

[30] Viviani was coerced under torture by the DOPS officers into signing a confession of embezzlement from Simonal's failing production company. When, following an investigation, the officers publicly claimed that Simonal was an informant on organizations and individuals opposed to the regime, most of the left and the music business believed them and, although officially exonerated by the President's office in 1995, he 
Treece, David. Música Popular Black and anti-racist struggles: musical cosmopolitanism and the soul aesthetic in Brazil (19631978).

never recovered from the ostracism that ensued. Simonal was posthumously rehabilitated by the National Human Rights Committee of the Brazilian Bar Association in 2003, and in 2008 the Afrobras institution and the Universidade Zumbi dos Palmares posthumously awarded him the Troféu Raça Negra (Morais, 2016, pp. 38-44). See also Alexandre, 2009, pp. 200-241.

[31] 'Subi lá no morro só pra ver o que o negro tem/ Pra sambar gostoso e fazer samba como ninguém.'

[32] ‘Podem me prender, podem me bater ... / Que eu não mudo de opinião/ Daqui do morro eu não saio não'; ‘O morro não tem vez . . ./ quando derem vez ao morro toda a cidade vai cantar'; 'Batucada surgiu, nenhum branco ficou /Pois ser branco é ter cor/ E pouco amor...'. From the album Wilson Simonal (1965).

[33] 'Sim, sou um negro de cor/ Meu irmao de minha cor/ O que te peço é luta sim, luta mais/ Que a luta está no fim ... . Cada negro que for/ Mais um negro virá/ Para lutar/ Com sangue ou não/ Com uma canção/ Também se luta, irmão/ Ouve minha voz/ Oh yes! Luta por nós/ Luta negra demais é lutar pela paz/ Para sermos iguais.'

[34] 'Reportagem Simonal: a luta como canção', Folha de São Paulo. Caderno Ilustrada, 18 March 1967, p. 2, apud Morais, 2016, p. 127.

[35] Available at: www.youtube.com/watch?v=FH0Ws4Sw0ZE (Accessed: 26 July 2021)

[36] Correio da Manhã, 4 December 1970, Supplement, p. 3.

[37] O Pasquim, 4, July 1969, apud. Alonso Ferreira, 2007, p. 245.

[38] Correio da Manhã, supplement, 4 December 1970, p. 3, apud Morais, 2016, p. 129.

[39] Available in the documentary Wilson Simonal-Ninguém Sabe o Duro que Dei, dir. Cláudio Manoel, 2009, Zohar Cinema/ Globo Filmes/TV Zero https://www.youtube.com/watch?v=ItVY5xs3 VM at 23' 47" to 25' 53" (Accessed: 26 July 2021). For a detailed commentary, see Morais, 2016, pp. 149-51.

[40] Araújo, G. (2007) 'Fui o primeiro metrossexual negro no Brasil', G1, 14 May [online]. Available at: http://g1.globo.com/Noticias/Brasil/0,_MUL33333-5598-3727,00.html (Accessed: 26 July 2021)

[41] See the festival footage, BR-3 -Tony Tornado e Trio Ternura -V FIC 1970 at: https://www.youtube.com/watch?v=3vmjyyNT88g (Accessed: 26 July 2021)

[42] 'A gente corre na BR-3/ E a gente morre na BR-3/ Há um crime/ No longo asfalto dessa estrada/ E uma notícia fabricada/ Pro novo herói de cada mês.'

[43] ‘Não sei por que você tem tanto orgulho assim/Você sempre me despreza/ Sei que sou negro, mas ninguém vai rir de mim/ Vê se entende, vê se ajuda/ O meu caráter não está na minha cor/ O que eu quero, não se iluda/

O que eu procuro é conseguir o seu amor.'

[44] ‘Hoje cedo, na rua do Ouvidor/ Quantos brancos horríveis eu vi/ Eu quero um homem de cor/ Um deus negro do Congo ou daqui/ Que se integre no meu sangue europeu// Black is beautiful, black is beautiful/ Black beauty so peaceful/ I wanna a black/ I wanna a beautiful'.

[45] Pacelli. S. (2015) 'Aos 84 anos, Tony Tornado fala da luta contra a ditadura e da sua carreira artística', UAI 6 December [Online]. Available at: https://www.uai.com.br/app/noticia/musica/2015/12/06/noticiasmusica,174864/o-gigante-chamado-tony.shtml (Accessed: 26 July 2021)

[46] See Eu também quero Mocotó (Erlon Chaves e sua banda Veneno), available at: https://www.youtube.com/watch?v=mxWsTeuo0M4(Accessed: 26 July 2021)

B 
[47] ‘Brother!/ Assuma sua mente, brother!/ E chegue a uma poderosa conclusão/ De que os blacks não querem ofender a ninguém, brother!/ O que nós queremos é dançar!/ Dançar, dançar e curtir muito soul'. The same theme is the subject of 'Esse É O Nosso Black Brother' (This is Our Black Brother), also on the album Gerson King Combo (Polydor, 1977). 